\title{
Front Matter: Volume 7621
}

, "Front Matter: Volume 7621," Proc. SPIE 7621, Optical Metro Networks and Short-Haul Systems II, 762101 (22 January 2010); doi: 10.1117/12.855153

SPIE. Event: SPIE OPTO, 2010, San Francisco, California, United States 


\title{
PROCEEDINGS OF SPIE
}

\section{Optical Metro Networks and Short-Haul Systems II}

\author{
Werner Weiershausen \\ Benjamin Dingel \\ Achyut Kumar Dutta \\ Atul K. Srivastava \\ Editors
}

27-28 January 2010

San Francisco, California, United States

Sponsored and Published by

SPIE 
The papers included in this volume were part of the technical conference cited on the cover and title page. Papers were selected and subject to review by the editors and conference program committee. Some conference presentations may not be available for publication. The papers published in these proceedings reflect the work and thoughts of the authors and are published herein as submitted. The publisher is not responsible for the validity of the information or for any outcomes resulting from reliance thereon.

Please use the following format to cite material from this book:

Author(s), "Title of Paper," in Optical Metro Networks and Short-Haul Systems II, edited by Werner Weiershausen, Benjamin Dingel, Achyut Kumar Dutta, Atul K. Srivastava, Proceedings of SPIE Vol. 7621 (SPIE, Bellingham, WA, 2010) Article CID Number.

ISSN 0277-786X

ISBN 9780819480170

Published by

SPIE

P.O. Box 10, Bellingham, Washington 98227-0010 USA

Telephone +1 3606763290 (Pacific Time) · Fax +1 3606471445

SPIE.org

Copyright (C) 2010, Society of Photo-Optical Instrumentation Engineers

Copying of material in this book for internal or personal use, or for the internal or personal use of specific clients, beyond the fair use provisions granted by the U.S. Copyright Law is authorized by SPIE subject to payment of copying fees. The Transactional Reporting Service base fee for this volume is $\$ 18.00$ per article (or portion thereof), which should be paid directly to the Copyright Clearance Center (CCC), 222 Rosewood Drive, Danvers, MA 01923. Payment may also be made electronically through CCC Online at copyright.com. Other copying for republication, resale, advertising or promotion, or any form of systematic or multiple reproduction of any material in this book is prohibited except with permission in writing from the publisher. The CCC fee code is 0277-786X/10/\$18.00.

Printed in the United States of America.

Publication of record for individual papers is online in the SPIE Digital Library.

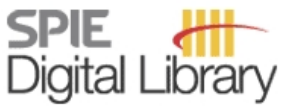

SPIEDigitalLibrary.org

Paper Numbering: Proceedings of SPIE follow an e-First publication model, with papers published first online and then in print and on CD-ROM. Papers are published as they are submitted and meet publication criteria. A unique, consistent, permanent citation identifier (CID) number is assigned to each article at the time of the first publication. Utilization of CIDs allows articles to be fully citable as soon they are published online, and connects the same identifier to all online, print, and electronic versions of the publication. SPIE uses a six-digit CID article numbering system in which:

- The first four digits correspond to the SPIE volume number.

- The last two digits indicate publication order within the volume using a Base 36 numbering system employing both numerals and letters. These two-number sets start with 00, 01, 02, 03, 04, $05,06,07,08,09,0 A, 0 B \ldots 0 Z$, followed by 10-1Z, 20-2Z, etc.

The CID number appears on each page of the manuscript. The complete citation is used on the first page, and an abbreviated version on subsequent pages. Numbers in the index correspond to the last two digits of the six-digit CID number. 


\title{
Contents
}

\author{
vii Conference Committee \\ ix Introduction
}

SESSION 1 FIBER OPTICS LINKS AND DEVICES: JOINT SESSION WITH CONFERENCE 7607

762102 Active and tunable waveguide devices based on silicon and silica for use in optical communication systems (Invited Paper) [7621-01]

E. Brinkmeyer, T. Pagel, T. Waterholter, M. Krause, H. Renner, Technische Univ.

Hamburg-Harburg (Germany)

762103 Optical transceivers for short and medium reach optical networks (Invited Paper) [7621-02]

B. Huebner, Finisar Corp. (United States)

\section{SESSION 2 METRO NETWORK ARCHITECTURE}

762104 Changing the network structure: leaving the past behind (Invited Paper) [7621-03]

R. Herber, T-Systems (Germany)

762105 Optical metro networks 2.0 (Invited Paper) [7621-04]

J.-P. Elbers, K. Grobe, ADVA AG Optical Networking (Germany)

762106 Recent development and future prospects of optical metro networks and their technologies (Invited Paper) [7621-05]

T. Invi, A. Sahara, T. Takahashi, NTT Network Innovation Labs. (Japan)

762107 All-optical grooming for $100 \mathrm{Gbit} / \mathrm{s}$ ethernet (Invited Paper) [7621-07]

J. Leuthold, R. Bonk, P. Vorreau, Institute of Photonics and Quantum Electronics, Karlsruhe Institute of Technology (Germany); S. Sygletos, Institute of Photonics and Quantum Electronics, Karlsruhe Institute of Technology (Germany) and Univ. College Cork (Ireland); D. Hillerkuss, W. Freude, Institute of Photonics and Quantum Electronics, Karlsruhe Institute of Technology (Germany); G. Zarris, D. Simeonidou, Univ. of Essex (United Kingdom);

C. Kouloumentas, M. Spyropoulou, I. Tomkos, Athens Information Technology (Greece);

F. Parmigiani, P. Petropoulos, D. J. Richardson, Univ. of Southampton (United Kingdom);

R. Weerasuriya, S. Ibrahim, A. D. Ellis, Univ. College Cork (Ireland); R. Morais, P. Monteiro,

Nokia Siemens Networks (Portugal); S. Ben Ezra, S. Tsadka, Finisar Israel (Israel)

\section{SESSION 3 COMPONENTS AND SUB-SYSTEMS FOR OPTICAL NETWORKS}

762108 In-service characterization of optical links and signals with respect to PMD (Invited Paper) [7621-06]

H. Rosenfeldt, Agilent Technologies (Germany); D. Werner, Alcatel-Lucent (Germany) 
762109 Phase-preserving amplitude noise suppression using an attenuation-imbalanced NOLM [7621-08]

E. Parsons, College of Optical Sciences, The Univ. of Arizona (United States); C. Stephan, Max Planck Institute for the Science of Light (Germany), Univ. of Erlangen-Nuremberg (Germany), and Erlangen Graduate School in Advanced Optical Technologies (Germany); K. Sponsel, Max Planck Institute for the Science of Light (Germany) and Univ. of Erlangen-Nuremberg (Germany); T. Roethlingshoefer, Max Planck Institute for the Science of Light (Germany), Univ. of Erlangen-Nuremberg (Germany), and Erlangen Graduate School in Advanced Optical Technologies (Germany); F. Kueppers, College of Optical Sciences, The Univ. of Arizona (United States); G. Onishchukov, Max Planck Institute for the Science of Light (Germany) and Erlangen Graduate School in Advanced Optical Technologies (Germany); B. Schmauss, Univ. of Erlangen-Nuremberg (Germany) and Erlangen Graduate School in Advanced Optical Technologies (Germany); G. Leuchs, Max Planck Institute for the Science of Light (Germany), Univ. of Erlangen-Nuremberg (Germany), and Erlangen Graduate School in Advanced Optical Technologies (Germany)

7621 OA Photonic balancing and its application in optical receivers and regenerators for fiber-optic systems (Invited Paper) [7621-09]

F. Kueppers, E. Parsons, H. Chaouch, College of Optical Sciences, The Univ. of Arizona (United States); W. Weiershausen, M. Mattila, A. Tervonen, T. von Lerber, Luxdyne Ltd. (Finland)

7621 OB Challenges and opportunities for optical amplifiers in metro optical networks (Invited Paper) [7621-10]

G. J. Cowle, JDSU (United States)

7621 OC All-optical $2 \times 2$ switch by exploiting optical nonlinearities in a single semiconductor optical amplifier [7621-11]

C. Porzi, CEIICP, Scuola Superiore Sant'Anna (Italy); L. Ma, Tsinghua Univ. (China);

M. Scaffardi, National Photonics Lab. (Italy); M. Yao, Tsinghua Univ. (China); L. Potì,

A. Bogoni, National Photonics Lab. (Italy)

\section{SESSION 4 ACCESS AND METRO NETWORK CONVERGENCE}

7621 OD NG-PON: enabling technologies for metro-access convergence (Invited Paper) [7621-12] F. J. Effenberger, Huawei Technologies (United States)

7621 OE Challenges of future converged access and metro networks (Invited Paper) [7621-13] D. Brever, R. Hülsermann, C. Lange, E. Weis, Deutsche Telekom AG (Germany)

7621 OF Effects of network node consolidation in optical access and aggregation networks on costs and power consumption [7621-14]

C. Lange, R. Hülsermann, D. Kosiankowski, F. Geilhardt, A. Gladisch, Deutsche Telekom AG (Germany) 
$7621 \mathrm{OH}$ Serial $100 \mathrm{Gbit} / \mathrm{s}$ PM-RZ-DQPSK transmission in the presence of perturbations from lower data rate neighboring channels [7621-16]

H. Chaouch, College of Optical Sciences, The Univ. of Arizona (United States); S. Vorbeck, M. Schneiders, Deutsche Telekom AG (Germany); F. Kueppers, College of Optical Sciences, The Univ. of Arizona (United States)

$762101 \quad$ Non-binary LDPC-coded modulation for high-speed optical metro networks with backpropagation [7621-17]

M. Arabaci, I. B. Djordjevic, The Univ. of Arizona (United States); R. Saunders,

R. M. Marcoccia, Opnext, Inc. (United States)

7621 0J Quaternary modulation formats for 100-Gbps optical links [7621-18]

T. F. Detwiler, S. M. Searcy, Georgia Institute of Technology (United States); R. Lingle, Jr., OFS (United States); E. B. Basch, Verizon (United States); S. E. Ralph, Georgia Institute of Technology (United States)

\section{SESSION 6 HIGH CAPACITY TRANSMISSION AND NEW MODULATION FORMATS II}

7621 OK Ultimate information capacity of fiber-optic networks (Invited Paper) [7621-19]

I. B. Djordjevic, The Univ. of Arizona (United States)

7621 OL DQPSK for metro networks [7621-20]

A. Stark, Y.-T. Hsueh, S. Searcy, C. Liu, Georgia Institute of Technology (United States);

A. McCurdy, R. Lingle, Jr., OFS (United States); M. Filer, S. Tibuleac, ADVA Optical Networking (United States); G.-K. Chang, S. E. Ralph, Georgia Institute of Technology (United States)

7621 OM Capacity achieving modulation format for high-speed optical networks [7621-21]

H. G. Batshon, I. B. Djordjevic, The Univ. of Arizona (United States); L. XU, T. Wang, NEC Labs. America (United States)

$7621 \mathrm{ON} \quad 1$ - $\mu \mathrm{m}$ waveband and C-band, 10-Gbps error-free operation of ultra-broadband photonic transport system with holey fiber [7621-22]

N. Yamamoto, National Institute of Information and Communications Technology (Japan); Y. Omigawa, Aoyama Gakuin Univ. (Japan); K. Akahane, T. Kawanishi, National Institute of Information and Communications Technology (Japan); H. Sotobayashi, National Institute of Information and Communications Technology (Japan) and Aoyama Gakuin Univ. (Japan)

762100 Experimental demonstration of simultaneous compensation of polarization mode dispersion and fiber nonlinearities by LDPC-coded turbo equalization [7621-23]

L. L. Minkov, I. B. Djordjevic, The Univ. of Arizona (United States)

7621 OP NLMS-based PMD equalization with improved adaption speed [7621-24]

D. Goelz, P. Meissner, Technische Univ. Darmstadt (Germany) 
POSTER SESSION

$76210 Q \quad$ Investigation of dense dispersion management optical links with non-perfect dispersion maps [7621-25]

V. A. Burdin, V. A. Andreev, M. V. Dashkov, K. A. Volkov, Povolzhskiy State Univ. of Telecommunications and Informatics (Russian Federation)

7621 OR Optical link upgrade by DDMS technique with compensating fiber in optical cable closure [7621-26]

V. A. Burdin, M. V. Dashkov, A. V. Bourdine, K. A. Volkov, Povolzhskiy State Univ. of Telecommunications and Informatics (Russian Federation)

Author Index 


\section{Conference Committee}

Symposium Chair

E. Fred Schubert, Rensselaer Polytechnic Institute (United States)

Symposium Cochairs

Liang-Chy Chien, Kent State University (United States)

James G. Grote, Air Force Research Laboratory (United States)

Program Track Chair

Benjamin Dingel, Nasfine Photonics, Inc. (United States)

Conference Chairs

Werner Weiershausen, Deutsche Telekom AG (Germany)

Benjamin Dingel, Nasfine Photonics, Inc. (United States)

Achyut Kumar Dutta, Banpil Photonics, Inc. (United States)

Atul K. Srivastava, OneTerabit (United States)

Program Committee

Ronald Freund, Fraunhofer-Institut für Nachrichtentechnik Heinrich-Hertz-Institut (Germany)

Franko Kueppers, College of Optical Sciences, The University of Arizona (United States)

Ralph Leppla, Deutsche Telekom AG (Germany)

Ernst-Dieter Schmidt, Siemens AG (Germany)

Sascha Vorbeck, Deutsche Telekom AG (Germany)

Winston I. Way, OpVista, Inc. (United States)

\section{Session Chairs}

$1 \quad$ Fiber Optics Links and Devices: Joint Session with Conference 7607

Yakov G. Soskind, David H. Pollock Consultants, Inc. (United States)

2 Metro Network Architecture

Atul K. Srivastava, OneTerabit (United States)

3 Components and Sub-Systems for Optical Networks

Werner Weiershausen, Deutsche Telekom AG (Germany) 
4 Access and Metro Network Convergence

Atul K. Srivastava, OneTerabit (United States)

$5 \quad$ High Capacity Transmission and New Modulation Formats I Werner Weiershausen, Deutsche Telekom AG (Germany)

$6 \quad$ High Capacity Transmission and New Modulation Formats II Achyut Kumar Dutta, Banpil Photonics, Inc. (United States) 


\section{Introduction}

It is our great pleasure to welcome you to the Optical Metro Networks and Short-Haul Systems II conference in the framework of the SPIE Photonics West OPTO 2010 symposium. It is one out of four conferences on optical communications with the focus on telecommunication networks, transmission systems, optical sub-systems, and components. The other three conferences comprise topics on broadband access and free-space laser communication, optoelectronic interconnects, and component integration.

The Optical Metro Networks and Short-Haul Systems II conference covers a large variety of basic topics such as metro network architectures, physical and protocol layer based technologies, telecommunication service enablers at component, and system level. It comprises technical and technoeconomic considerations.

The focus is not on ULH transmission but on metro and short haul networks which are of increasing importance as their large-scale network element deployment offers a huge potential for future cost reduction in the domains of capital and operational expenditures and energy efficiency optimization. Although ULH is not the primary focus of this conference and proceedings edition, a lot of important innovative technologies are discussed here that many people know from optical long haul fibre transmission. This is quite consequential as the domains and technologies of short haul/metro and long haul are growing together more and more these days. Robust fiber transmission and wavelength division multiplexing approaches, new modulation formats and equalizer schemes, and other innovations known from the long haul field will urgently be needed in future metro/short haul network domains due to today's dramatic increase of bandwidth and bitrate speed demands.

We expect this conference to continue as a lead venue in sharing new technical advances and bringing innovative integrated approaches that address key issues in WDM transmission systems and optical networks for short haul and metro domains.

Finally, we express our strong appreciation to the authors of all the contributed and invited papers, the technical program committee members, the session supporting professionals, and the SPIE staff who made this conference possible and enriching. The success of this conference is strongly due to them.

Thank you for joining us at the Optical Metro Networks and Short-Haul Systems Il conference of the SPIE Photonics West OPTO 2010 symposium

Werner Weiershausen
Benjamin Dingel
Achyut Kumar Dutta
Atul K. Srivastava 
Downloaded From: https://www.spiedigitallibrary.org/conference-proceedings-of-spie on 26 Apr 2023

Terms of Use: https://www.spiedigitallibrary.org/terms-of-use 